\title{
Spatial and Temporal Variation of Drought in Far and Mid Western Regions of Nepal: Time Series Analysis (1982-2012)
}

\author{
Hemu Kharel Kafle \\ Nepal Academy of Science and Technology, Lalitpur, Nepal \\ e-mail: hemukafle@gmail.com
}

\begin{abstract}
Recent and potential future increases in global temperature are likely to be associated with impacts on the hydrological cycle, including changes to precipitation and increases in extreme events such as droughts. This study has investigated the spatial and temporal changes in drought occurrence in far and mid-western regions of Nepal. Quantification of the severity and frequency of drought within different physiographical regions have been worked out with the help of Standardized Reconnaissance Drought Index $\left(\mathrm{RDI}_{\mathrm{st}}\right)$. Time series analyses of mean annual rainfall and annual temperature datasets of 16 meteorological stations covering far and mid western development regions from 19822012 have been used. It has been revealed that all the three kinds (moderate, severe and extreme) of droughts occurred in the study area. Extreme drought was recorded in four stations (Dadeldhura, Patan, Tikapur and Silgadhi) of far west region and five stations (Musikot, Dailekh, Surkhet, Tulsipur and Khajura) of mid western region. These events occurred when precipitation recorded its lowest range. Most frequent droughts were observed in Dhangadhi, Dadeldhura and Jumla. There were higher number of droughts in far western region but more extreme events occurred in mid western region. No clear correlation was found between temperature and precipitation trends in five selected stations except in Dhangadi that lies in Terai region.
\end{abstract}

Key words: drought, far and mid western regions, reconnaissance drought index (RDI)

\section{Introduction}

Drought is a natural local or regional phenomenon, its basic cause being the lack of precipitation over a time period. Precipitation is the primary factor controlling the formation and persistence of drought conditions. Other climatic factors such as high temperature, high wind, and low relative humidity are often associated with it in many regions of the world and can significantly aggravate its severity (Kundzewicz 1997). A combination of droughts or sequences of droughts have serious impacts on human and environmental welfare (Sheffield \& Wood 2008). Of all the natural disasters, the economic and environmental consequences of drought are among the highest, due primarily to the longevity and widespread spatial and extent of many droughts (Willhite 2000). With the increase in extreme climatic events, droughts are projected to become more frequent and severe with global warming (Trenberth et al. 2014), in particular, during the warmest decade of the twenty-first century, 17-35\% of global land area experienced moderate droughts, 7-15\% experienced severe droughts, and 2-6 \% experienced extreme droughts (Kogan et al. 2013). Therefore, it is essential for droughts to be accurately and persistently monitored for mitigating its adverse effects on national and regional scales.

Nepal is a land-locked country situated in the middle belt of the Himalayas, having an area of $145305 \mathrm{~km}^{2}$ and a population of 11.6 million. The climate here varies from tropical in the southern plain to temperate in the central region, and from arctic in the higher Himalayas to arid in the Trans Himalayas. Since Nepal is located at the northern-most edge of the South Asian 
monsoon system, the wet season is relatively short (Saha 2010) lasting from mid-June to August / September in contrast to the Indian subcontinent monsoon while the dry season persists somewhat longer (Shrestha 2000). Nepal is divided into five development regions - east, west, central, mid-west and far west. As the monsoon comes from the east, it first strikes eastern Nepal and then it slowly proceeds to the west.

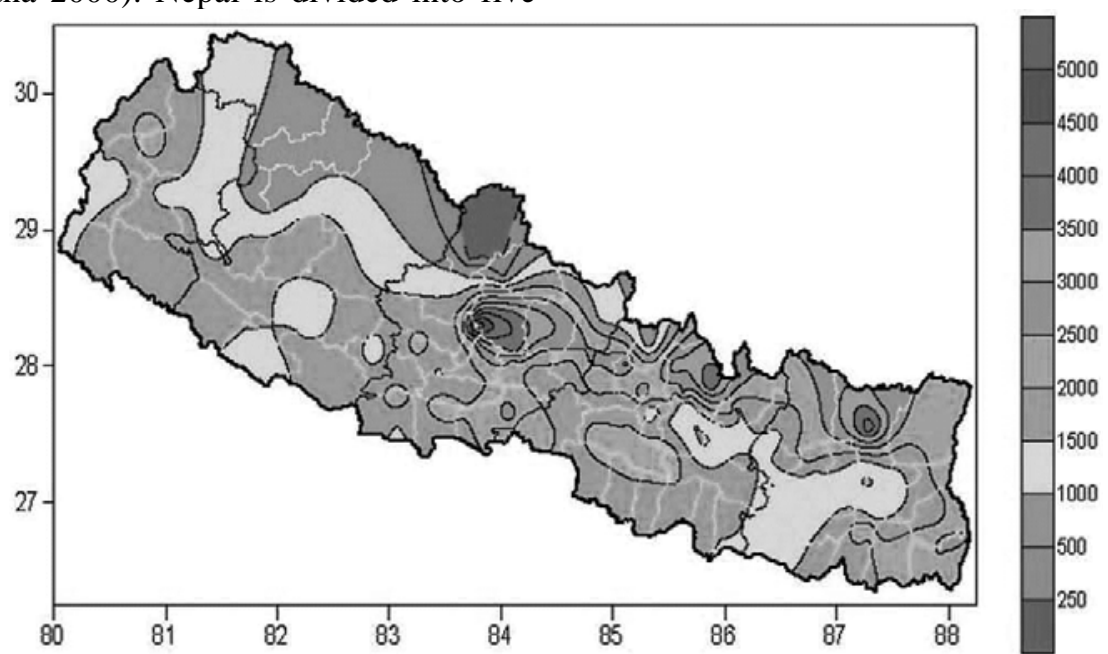

Fig.1 Annual mean rainfall pattern (mm) over Nepal (Source: Practical Action Nepal Office 2009)

While moving towards the western parts of the country, the cloud stream follows a westerly course and part of it follows the river valleys to the north. It takes nearly one month for the monsoon to reach the western border of Nepal (Gautam \& Regmi 2014). Likewise, the westerlies move from west to east. In both these cases the intensity of rainfall varies in space and time (DIHM 1974). The amount of rainfall is much higher in the eastern region and substantially decreases from the east to west. The western half, especially the northern parts of mid western development region are generally drier compared to the eastern half as shown in Fig. 1

Moreover, temperature is directly related to season and altitude of the location. The hottest part of the country is the southern tarai belt and the coldest part lies in the high mountain or the Himalayas in the north (Fig. 2). Altitude is the guidance factor in the spatial variation of temperature.

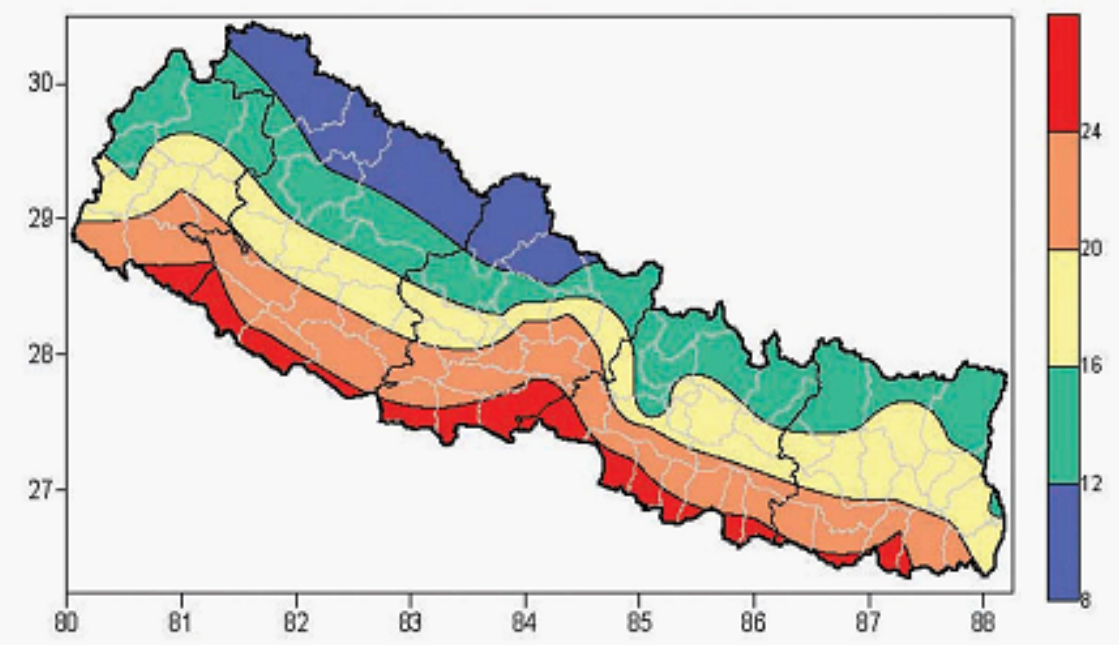

Fig. 2. Spatial variation of mean temperature $\left({ }^{\circ} \mathrm{C}\right)$ (Source: Practical Action Nepal Office 2009) 
In Nepal, temperature is lowest during winter (December - January) and increases as spring advances due to increase in solar insolation. However, the arrival of monsoon rain checks the increase in temperature making generally May or early June the hottest months. The temperature starts decreasing from October and reaches the minimum in December or January.

Although it is not possible to avoid droughts they can be predicted, monitored, and their adverse impacts can be alleviated by regular monitoring of potential regions at high risk of drought. Careful monitoring as well as early warning for dryness is a big challenge for drought management in Nepal. However, very few studies on drought of Nepal have been reported so far (Sikdel \& Ikada 2010, Shakya \& Yamaguchi 2010). A detailed study on drought occurrence and its measurement in far and mid western region (FMWD) using the standardized reconnaissance drought index (RDI), covering the period 1982-2012 has been presented. This index used both precipitation and temperature as input parameters, which are suitable for quantifying the variations in severity and duration of drought. The objective of this study was to find out the spatial and temporal occurrence of drought and evaluate its nature associated with precipitation and temperature pattern.

\section{Study Area}

\section{Far-Western Development Region}

Spatial distribution of all studied meteorological stations of Far Western development region (FWD) (Patan, Dadeldhura, Mahendranagar, Darchula, Chainpur, Silgadhi, Tikapur, Dhangadhi and Dipayal), are shown in Fig. 3. Physiographically this region contains all five regions: Terai in the south, the Siwalik and Middle Mountain in the middle and High Mountains and Himalayan in the north. The area of FWD is 19,539 square kilometer, the smallest among the development regions. River Karnali is situated in the eastern boundary and River Mahakali in the western boundary. This region is influenced by the monsoon wind which comes from the northwest bringing enough rainfall in winter, thus gets more rainfall in winter than in summer.

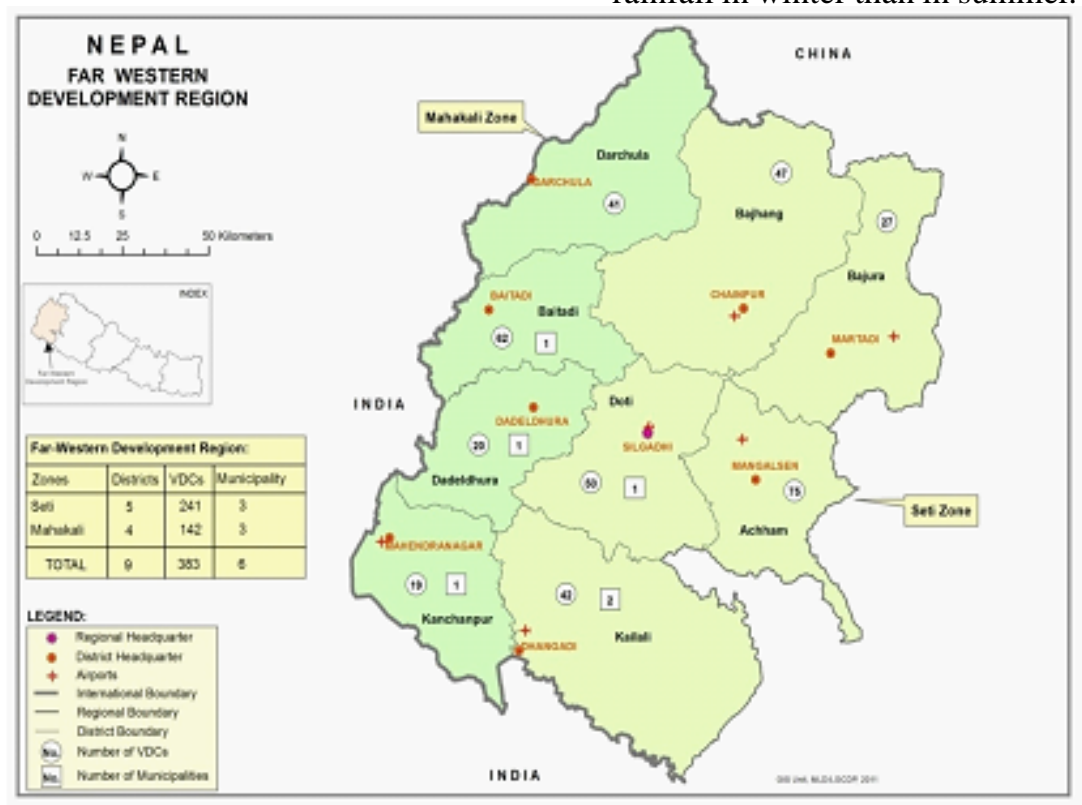

Fig. 3. Map of far-western development region of Nepal (Source: lgcdp.gov.np/home/map-center.php)

\section{Mid -Western Development Region}

Mid Western development region (MWD) is the largest of the five development regions of Nepal. It has the same five physiographical zones as the other regions: Terai, Siwalik, Middle Mountain, High Mountain and Himalaya. It has some of the most remote and economically depressed areas of the country, in particular the Karnali Zone. The climate varies from alpine in the high Himalayan area to tropical/subtropical in the Terai region. The spatial distributions of seven MWD meteorological stations are shown in Fig. 4. 


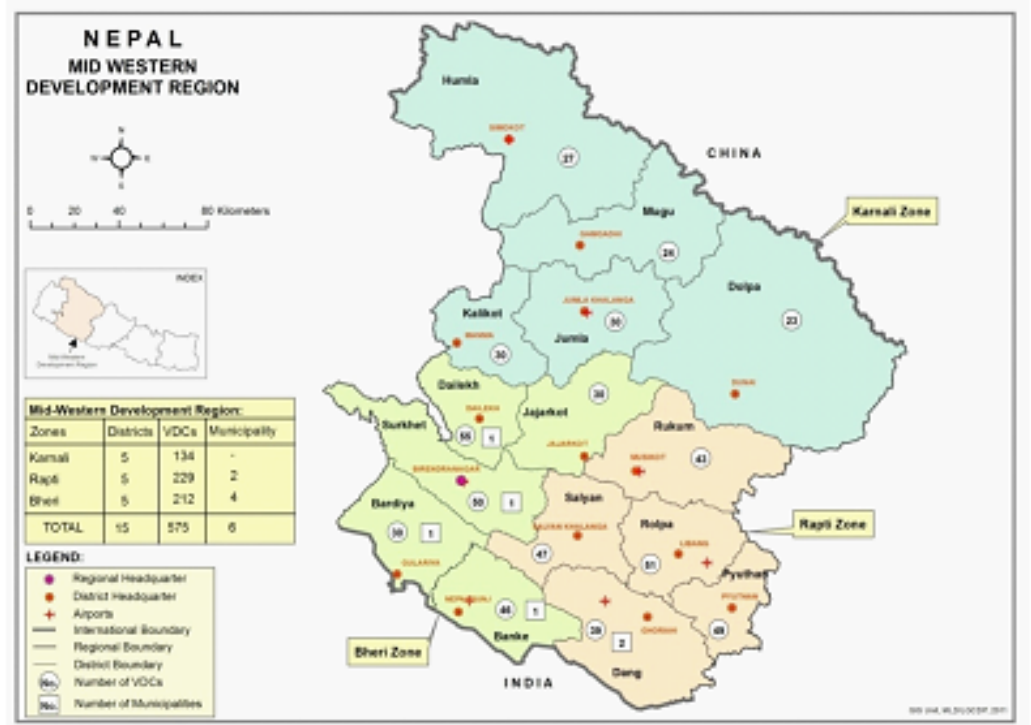

Fig. 4. Map of mid-western development region of Nepal (Source: lgcdp.gov.np/home/map-center.php)

\section{Methodology}

\section{A. Drought indices}

Drought indices are important elements of drought monitoring and assessment since they simplify complex interrelationships between many climate and climate-related parameters. Along the various indices proposed for characterization of meteorological drought, two widely accepted and used are the Palmer's drought severity Index (PDSI) (Palmer 1965, Guttman et al. 1992) and the standardized precipitation Index (SPI) (McKee 1995, Agnew 2000). The Palmer Index uses precipitation, evapotranspiration and soil moisture conditions as the key determinants, which are not recorded in all meteorological stations, therefore it is difficult to use for spatial analysis. On the other hand SPI index uses only one meteorological parameter, precipitation, for describing the water deficit. However meteorological drought conceived as a water deficit should be approached by a sort of balance between input and output (Tsakiris \& Vangelis 2005). A step forward could be to consider the balance between two major meteorological parameters such as precipitation $(\mathrm{P})$ (input) and potential evapotranspiration (PET) (output).

\section{Reconnaissance drought index}

Reconnaissance drought index (RDI) is based on the ratio between two aggregated quantities of precipitation and potential evapotranspiration
(Tsakiris \& Vangelis 2005). The initial value of the index for a certain period, indicated by a certain month (k) during a year, is calculated by the following equation:

$a_{k}=\frac{\sum_{i=1}^{i} k r_{j}^{k}}{\sum_{j=1}^{j=\underline{j}} P L F_{i}^{\prime}}$

In which $P_{j}$ and $i^{2} E T_{j}$ are the precipitation and potential evapotranspiration of the $\mathrm{j}^{\text {th }}$ month of the hydrological year. PET is calculated with the Thronthwaite formulas and adjusted to Penman with a correction factor, according to the United Nations Convention to Combat Desertification (UNEP 1992). Thronthwaite method of calculating Aridity Index is well known and has been used for classifying the climate of USA (Thronthwaite 1931), as well as for the classification of the climates of earth and others (Thronthwaite 1933, 1957, 1948, Kafle 2009). The hydrological year for the FMWD region starts in January, hence for January $\mathrm{k}=1$. Equation 1 may be calculated for any period of the year. It can be also written starting from any month of the year. For real world applications if $\alpha_{k}$ is calculated as a general indicator of meteorological drought, it is advisable to use periods of 3, 6, 9 and 12 months. In this case 12 month period $\left(a_{12}\right)$ is selected. The two expressions of the new index are the Normalized RDI and the Standardized RDI. The Normalized RDI $\left(R D I_{n}\right)$ is computed using the following equation: 
Hemu Kharel Kafle/Spatial and Temporal Variation.........

$$
R D I_{\mathrm{n}}(h)=\frac{e_{k}}{u_{k}}-1
$$

Finally, the Standardized RDI $\left(R D I_{s t}\right)$ is computed as follows:

$\operatorname{RDI}_{\mathrm{sr}}(k)=\frac{y_{k}-\ddot{r}_{k}}{\dot{\sigma}_{k}}$

In which $y_{k}$ is the $\ln a_{k}, \tilde{y}_{k}$ is its arithmetic mean and $\grave{\sigma}_{k}$ is its standard deviation.

Table 1. Classification of drought categories based on SPI index (McKee et al. 1993)

\begin{tabular}{l|l}
\hline SPI & Category \\
\hline Less than -1.0 & Moderate drought \\
Less than -1.5 & Severe drought \\
Less than -2.0 & Extre me drought \\
\hline
\end{tabular}

Regarding equation 3 , the standardization was achieved by assuming that $\alpha_{k}$ follows a lognormal distribution. The standardized RDI $\left(R D I_{s t}\right)$, behave in a generally similar way to the SPI, and therefore the interpretation of the results is similar since the same thresholds as SPI can be used as shown in Table 1. Hazard assessment of drought was evaluated in terms of frequency and severity. The linear trend (regression line) of temperature and precipitation were also evaluated for the last 30 years.

\section{B. Datasets used in the study}

Monthly rainfall and temperature datasets of 16 meteorological stations from 1982 to 2012 were obtained from the Department of Hydrology and Meteorology, Government of Nepal.

Table 2. Studied meteorological stations of far-western development region of Nepal

\begin{tabular}{l|l|l|l|l|l}
\hline Station Name & Latitude & Longitude & Altitude & Period & Physiographic region \\
\hline Dadeldhura & $29^{\circ} 18^{\prime}$ & $80^{\circ} 35^{\prime}$ & 1848 & $1982-2010$ & Middle mountain \\
Silgadhi Doti & $29^{\circ} 16^{\prime}$ & $80^{\circ} 59^{\prime}$ & 1360 & $1987-2012$ & Middle mountain \\
Chainpur & $29^{\circ} 33^{\prime}$ & $81^{\circ} 13^{\prime}$ & 1304 & $1987-2010$ & Himalayan region \\
Darchula & $29^{\circ} 51^{\prime}$ & $80^{\circ} 34^{\prime}$ & 1097 & $1989-2012$ & High mountain \\
Patan (Baitadi) & $29^{\circ} 14^{\prime}$ & $80^{\circ} 56^{\prime}$ & 720 & $1988-2011$ & Middle mountain \\
Dipayal (Dot) & $29^{\circ} 14^{\prime}$ & $80^{\circ} 56^{\prime}$ & 720 & $1988-2011$ & Middle mountain \\
Dhangadhi & $28^{\circ} 48^{\prime}$ & $80^{\circ} 03^{\prime}$ & 187 & $1982-2011$ & Tarai \\
Mahendra nagar & $29^{\circ} 02^{\prime}$ & $80^{\circ} 13^{\prime}$ & 176 & $1987-2012$ & Tarai \\
Tikapur & $28^{\circ} 32^{\prime}$ & $81^{\circ} 07^{\prime}$ & 140 & $1988-2012$ & Tarai \\
\hline
\end{tabular}

Nine meteorological stations are from FWD and seven are from MWD. Within available datasets, length of rainfall and temperature series differed widely, with only those stations with at least a continuous 22-years of record has being used in this study so enabling a longer-term perspective on drought. Temperature and precipitation trends of selected stations according to the physiographical regions, Jumla (Himalayan), Musikot (High Mountain), Dadeldhura (Middle Mountain), Surkhet (Siwalik) and Dhangadhi (Tarai) have been included in this article. Studied stations from FWD and MWD with their latitude, longitude, altitude, record length and physiographical types have been shown in Table 2 and 3 respectively.

Table 3. Studied meteorological stations of mid-western development region of Nepal

\begin{tabular}{l|l|l|l|l|l}
\hline Station Narne & Latitude & Longitude & Altitude & Period & Physiographic region \\
\hline Jurnla & $29^{\circ} 17^{\prime \prime}$ & $82^{\circ} 10^{\prime}$ & 2300 & $1982-2012$ & Hirnalayan region \\
Musikot & $28^{\circ} 38^{\prime}$ & $82^{\circ} 29^{\prime}$ & 2100 & $1988-2012$ & High mountain \\
Salyan Bazar & $28^{\circ} 23^{\prime}$ & $82^{\circ} 10^{\prime}$ & 1457 & $1988-2011$ & Middle mountain \\
Dailekh & $28^{\circ} 51^{\prime}$ & $81^{\circ} 43^{\prime}$ & 1402 & $1987-2011$ & Middle mountain \\
Tulsipur & $28^{\circ} 08^{\prime}$ & $82^{\circ} 18^{\prime}$ & 725 & $1982-2011$ & Tarai \\
Surkhet & $28^{\circ} 36^{\prime}$ & $81^{\circ} 37^{\prime}$ & 720 & $1982-2012$ & Siwalik \\
Khajura & $28^{\circ} 06^{\prime}$ & $81^{\circ} 34^{\prime}$ & 190 & $1982-2011$ & Tarai \\
& & & & & \\
\hline
\end{tabular}




\section{Results and Discussion}

\section{Drought analysis using RDI ${ }_{\mathrm{st}}$ Index for FWD}

Standarized RDI $\left(R D I_{s t}\right)$ have been calculated for all the studied stations using Equation 3. Since $\mathrm{RDI}_{\text {st }}$ behaves in a generally similar way to the SPI index and therefore the interpretation of the results are similar. Table 1 has been used for evaluating severity of drought (moderate, severe and extreme).
Drought index of all the nine meteorological stations of FWD have been shown in Table 4. The results showed that all the 9 stations faced drought conditions besides their physiographical differences. Occurrence of extreme droughts were observed at Dadeldhura and Patan in the year 1999 with standardized RDI values of -2.3 and -2.4 respectively; Silgadhi in the year 2010 with RDI value of -2.69 , and Tikapur in the year 1994 with RDI value -2.02 .

Table 4. Calculated RDI values in drought years for eight stations of far western region

\begin{tabular}{|c|c|c|c|c|c|c|c|c|}
\hline Year & Dade ldhura & Silgadhi & Chainpur & Darchula & Patan & Dipayal & Dhangadhi & Tikapur \\
\hline 1986 & & & & & & & -1.05 & \\
\hline 1987 & -1.4 & & & & & & -1.33 & \\
\hline 1989 & -1.43 & & & & & & & \\
\hline 1992 & -1.33 & & & & -1.65 & -1.86 & -1.07 & \\
\hline 1993 & & & -1.82 & & & & & \\
\hline 1994 & & & -1.36 & -1.55 & -1.35 & -1.68 & -1.59 & -2.02 \\
\hline 1999 & -2.3 & & & & -2.42 & -1.43 & & \\
\hline 2000 & & -1.38 & & & & & & \\
\hline 2001 & & & -1.17 & & & & -1.03 & \\
\hline 2004 & & & -1.4 & & & & -1.2 & \\
\hline 2005 & & & & & & & & -1.86 \\
\hline 2006 & -1.7 & & & & & & -1.21 & \\
\hline 2007 & & -1.53 & & & & & & \\
\hline 2008 & & -1.52 & & & & & & \\
\hline 2010 & & -2.69 & -1.12 & & & & & -1.38 \\
\hline
\end{tabular}

Within nine studied stations of FWD, highest number of droughts occurred at Dhangadi, seven drought years, $1986(-1.05), 1987(-1.33), 1992(-1.07), 1994$ $(-1.59), 2001(-1.03), 2004(-1.2)$ and $2006(-1.21)$ in 30 years; and at Dadeldhura, six drought years, 1987 (-1.4), 1989 (-1.43), $1992(-1.33), 1999(-2.3)$ and $2006(-1.7)$ in 28 years. Similarly, least number of drought year, was recorded in Darchula in 1994 $(-1.55)$ in 22 years. Similarly, meteorological stations observing three drought years are Patan in 1992 (-1.65), $1994(-1.35)$, and $1999(-2.42)$ in 21 years; Dipayal in $1992(-1.86), 1994(-1.68), 1999$ $(-1.43)$ in 22 years and Tikapur in $1994(-2.02), 2005$ $(-1.86)$ and $2010(-1.38)$ in 24 years. Moreover, continuous droughts were recorded in Silgadhi in the year 2007, 2008, Chainpur in the year 1993, 1994, and Dipayal in the year 1986 and 1987. Although, no similarity was observed in the drought year of FWD for all the studied station, most stations experienced drought in 1992, 1994, 1999, 2006 and 2010, as we can see from Table 4.
Drought analysis using RDI $_{\text {st }}$ index for MWD Calculated droughts using $R D l_{s t}$ index in seven meteorological stations of mid western region have been shown in Table 5. The stations covered all five physiographic regions. Highest number of drought (six drought years in 30 years) occurred in Jumla in 1984 (-1.81), 1987 (-1.11), 1999 (-1.53), 2004 (-1.36), 2005 $(-1.42)$ and $2009(-1.31)$ which lies in Himalayan region with an altitude of $2300 \mathrm{~m}$. Similarly, lowest number of droughts occurred (three drought years) in Musikot in 1989 (-2.66), 1993 (-1.16) and 2006 (-1.76) in 24 years and Khajura in 1998 with RDI value of2.21 in 29 years. These two stations lie in High Mountain and Terai regions with an altitude of 2100 $\mathrm{m}$ and $190 \mathrm{~m}$ respectively. Two continuous drought years were obtained in Jumla in the year 2004, 2005 and Salyan in the year 1991, 1992 of MWD. Extreme drought was seen in five meteorological stations of MWD, Musikot in the year 1989 (-2.66), Dailekh in the year $2010(-2.25)$, Tulsipur in the year $1996(-2.03)$ and 1999 (-2.24), Surkhet in the year $2010(-2.86)$ and Khajura in the year $1996(-2.21)$. 
Hemu Kharel Kafle/Spatial and Temporal Variation

Table 5. Calculated $R D I_{s t}$ values in drought years for seven stations of Mid Western Region

\begin{tabular}{|c|c|c|c|c|c|c|c|}
\hline Year & Jumla & Musikot & Salyan Bazar & Dailekh & Tulsipur & Surkhet & Khajura \\
\hline 1984 & -1.81 & & & & & & \\
\hline 1987 & -1.11 & & & & & -1.32 & \\
\hline 1989 & & -2.66 & & & & & \\
\hline 1991 & & & -1.4 & & & & \\
\hline 1992 & & & -1.61 & & -1.5 & & \\
\hline 1993 & & -1.16 & & & & & \\
\hline 1994 & & & -1.31 & & -2.03 & -1.29 & \\
\hline 1996 & & & & & & & -2.21 \\
\hline 1998 & & & & & -2.241 & & \\
\hline 1999 & -1.53 & & & & & & \\
\hline 2002 & & & & & & & -1.56 \\
\hline 2004 & -1.36 & & & & & & \\
\hline 2005 & -1.42 & & & & & & \\
\hline 2006 & & -1.76 & -1.28 & & -1.1 & & \\
\hline 2009 & -1.31 & & & & & & \\
\hline 2010 & & & & -2.25 & & -2.86 & \\
\hline 2011 & & & & & -1.56 & & \\
\hline 2012 & & & & & & -1.79 & \\
\hline
\end{tabular}

Among seven studied stations, Tulsipur that lies in Tarai region experienced two extreme drought events within 29 years of studied period. Calculated drought year in most of the stations of MWD are 1992, 1994, 2006 and 2010.

\section{Precipitation and temperature trends at selected stations}

The spatial and temporal distributions of mean annual temperature and precipitation trends of five selected stations have been shown in Fig. 5 to Fig. 9. These stations were selected in such a manner that they could represent all the five physiographical regions, having longest recorded period (having both highest and lowest number of drought years and experienced extreme drought events as well as continuous drought).

\section{Dhangadhi (Terai)}

Dhangadhi meteorological station lies in Tarai region at an altitude of $187 \mathrm{~m}$. Mean annual precipitation and temperature trend of this station is shown in Fig. 5. This figure showed just opposite trend for precipitation and temperature: when precipitation was decreasing temperature was increasing. Mean annual precipitation for 29 years ranged from $1000 \mathrm{~mm}$ to $3000 \mathrm{~mm}$ whereas temperature ranged from $21^{\circ} \mathrm{C}$ to $25^{\circ} \mathrm{C}$.

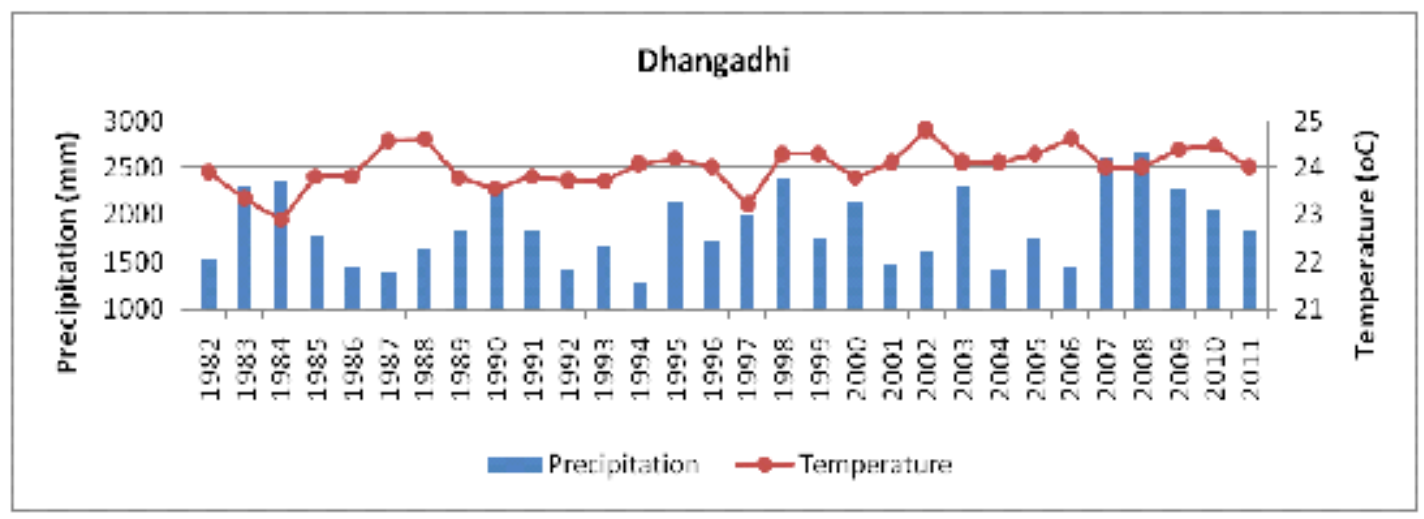

Fig. 5. Precipitation and temperature trend at Dhangadhi meteorological station 
This station experienced 7 droughts years in 29 years. However, there were no extreme drought events as well as continuous drought in this station.

\section{Surkhet (Siwalik)}

Surkhet meteorological station lies in Siwalik region at an altitude of $720 \mathrm{~m}$. Mean annual temperature and precipitation for 30 years showed a mixed trend (Fig. 6). Mean annual precipitations ranged from 900 to $2100 \mathrm{~mm}$ and mean annual temperatures ranged from 20 to $23^{\circ} \mathrm{C}$. This station experienced extreme drought in 2010 when the precipitation was in its minimum range and temperature in its maximum range. Altogether there were four drought years within 30 years of the studied period, continuous droughts were not recorded at this station. Precipitation trend was highly fluctuating, while temperature was in increasing trend in this station. There were not any correlation between precipitation and temperature trend.

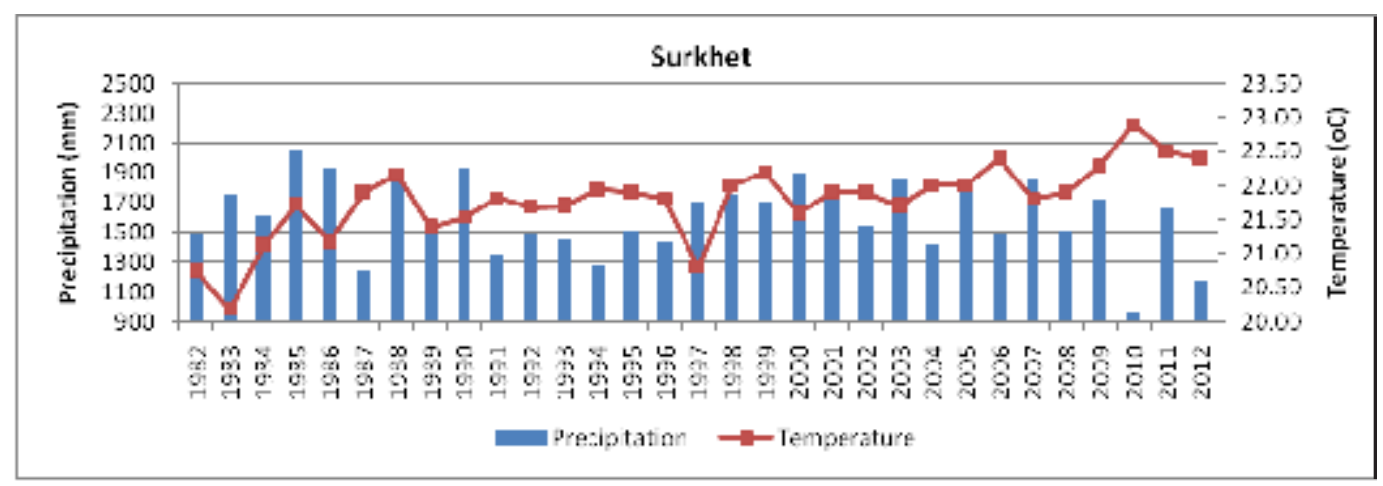

Fig. 6. Precipitation and temperature trends at Surkhet meteorological station

\section{Dadeldhura (Middle mountain)}

Dadeldhura meteorological station lies in the middle mountain region at an altitude of $1848 \mathrm{~m}$. Mean annual precipitation and temperature trends of 28 years are shown in Fig. 7. Precipitation ranged from 500 to 2000 $\mathrm{mm}$ whereas temperature ranged from 14 to $18^{\circ} \mathrm{C}$. No clear cut relation was found between precipitation and temperature for this station. There was decreasing trend in precipitation from 1990 to 1992 and also in 2003 to 2006. Minimum value of precipitation was in the year 1999, in this year Dadeldhura station experienced extreme drought event. There were altogether six drought events within 28 years of studied period of this station and continuous drought in 2005 and 2006.

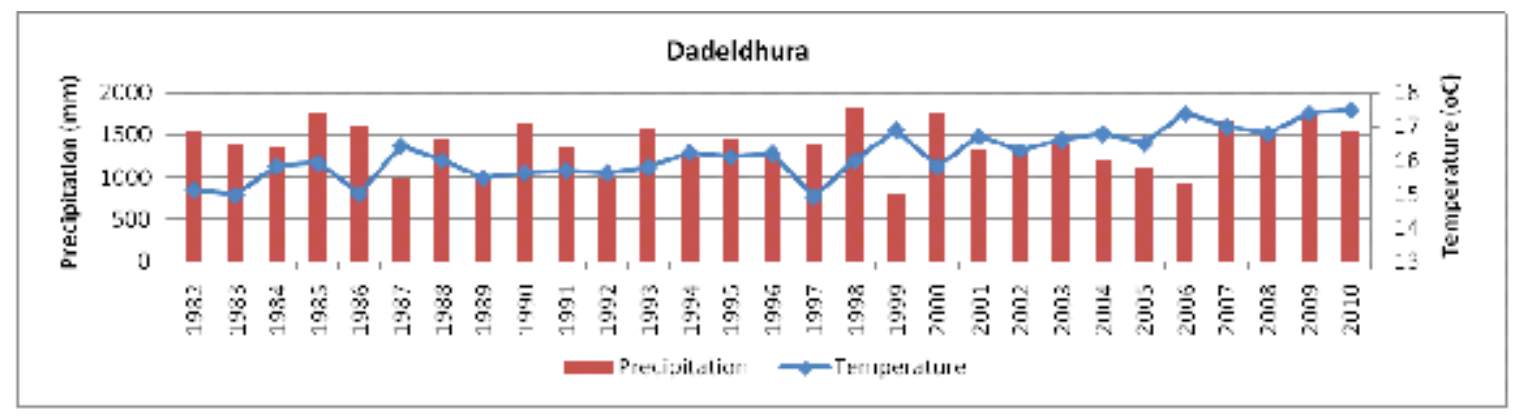

Fig. 7. Precipitation and temperature trend at Dadeldhura meteorological station

\section{Musikot (High mountain)}

Musikot meteorological station lies in High Mountain region at an altitude of $2100 \mathrm{~m}$. Fluctuating trend in precipitation was observed here. Temperature was stable from 1988 to 1995 and fluctuating later on
(Fig. 8). Precipitation ranged from 1000 to $2800 \mathrm{~mm}$ while temperature ranged from 17 to $21^{\circ} \mathrm{C}$ within 24 years of studied period. Correlation between temperature and precipitation was not found. Musikot experienced lowest precipitation level in 1989 and 
highest in 2010. In 1989 it experienced extreme drought event. There were altogether three droughts within 24 years and no continuous drought was observed in this station.

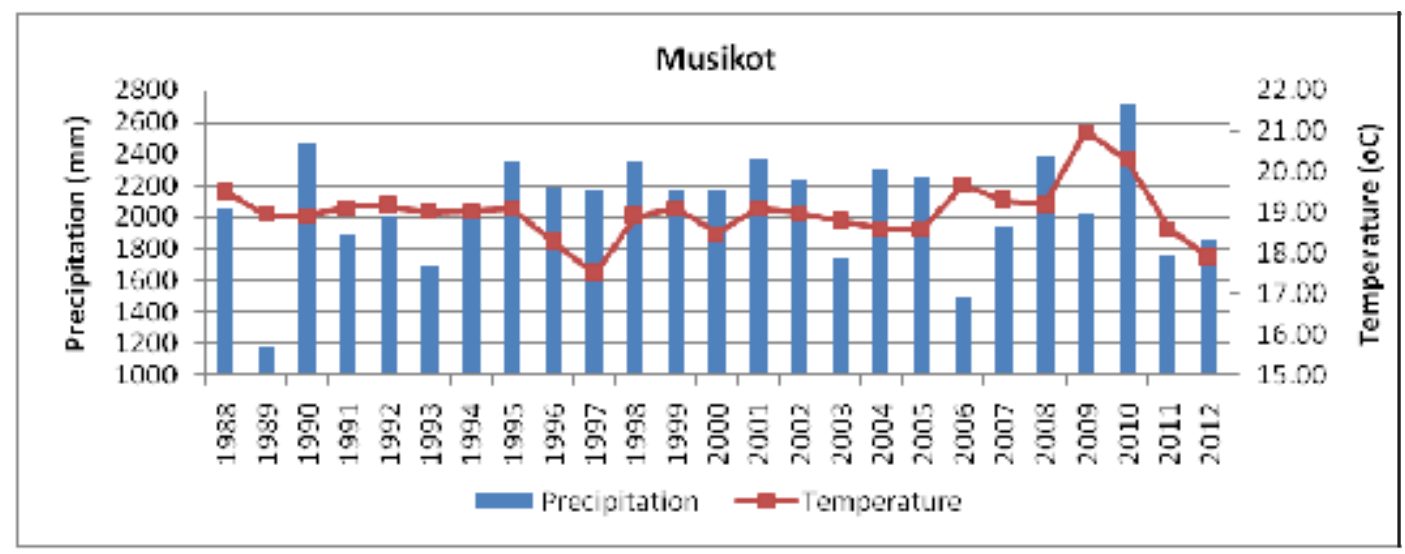

Fig. 8. Precipitation and temperature trend at Musikot meteorological station

\section{Jumla (Himalayan)}

Jumla meteorological station lies in Himalayan region at an altitude of $2300 \mathrm{~m}$. Fig. 9 shows the mean annual temperature and mean annual precipitation trend of this station for the 30 years period. Temperature was almost constant and precipitation was highly fluctuated, ranging between 600 to $1100 \mathrm{~mm}$ whereas temperatures were 12 to $13^{\circ} \mathrm{C}$ except in the year 2000 . Jumla observed six drought years in 30 years period. There were not any extreme droughts except a continuous drought in 2004 to 2005 . The temperature had increasing trend from 2001. Jumla experienced lowest precipitation in the year 1984 and highest in 1982. Temperature was lowest in 2000.

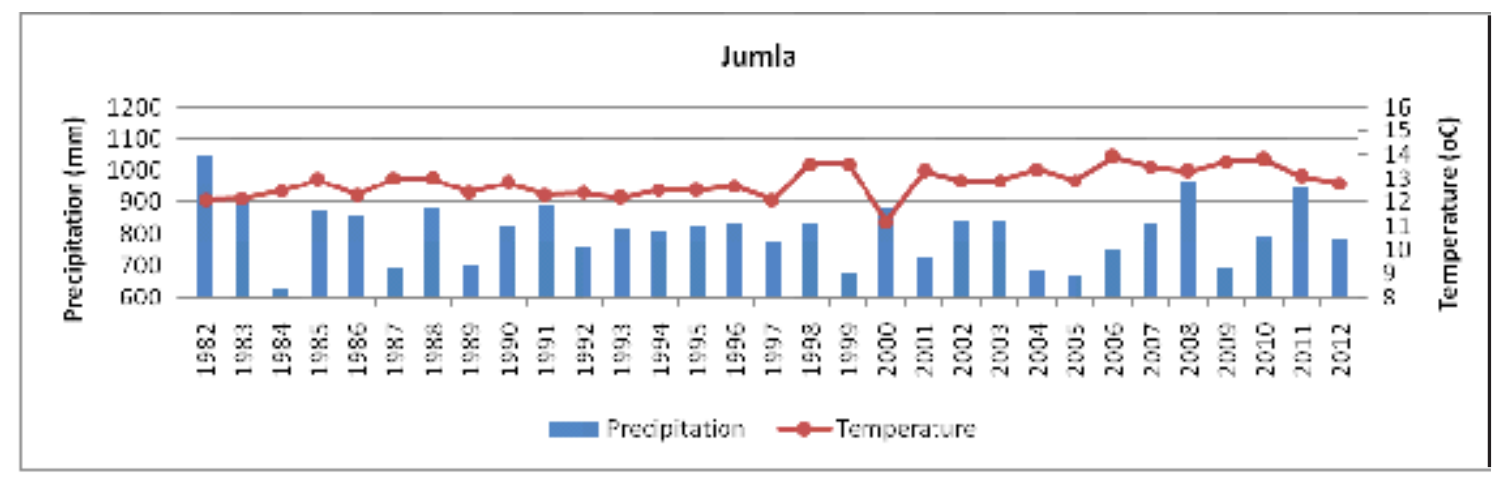

Fig. 9. Precipitation and temperature trend at Jumla meteorological station

There were clear drought events in all of the studied stations. Interestingly drought years were different for different meteorological stations. Though some stations experienced drought in the same year, but could not see any specific trend according to physiographical regions or altitude. Calculated drought years in most of the stations were 1992, 1994, 1999, 2006 and 2010. The highest numbers of drought events were observed in Dadeldhura (Middle Mountain), Jumla (Himalayan), Chainpur (Himalayan), Dailekh
(Middle Mountain), Dhangadhi (Tarai), Mahendranagar (Tarai) and Tulsipur (Tarai). Extreme drought events occurred when the precipitation recorded its lowest range. This study showed that the stations at higher altitude (Himalaya) and lowest altitude (Tarai) experienced greater number of droughts than in other regions. Some studies on precipitation, temperature and climatic patterns over Nepal (Shrestha 2000, Shrestha et al. 1999, Baidya et al. 2008) have also revealed warming trends at a bit 
higher magnitude in mountainous regions of Nepal. It was clear that the major factor for drought in far and mid western region of Nepal was the lack of precipitation linked with summer monsoon and winter time circulations. No clear correlation was found between temperature and precipitation trends in five selected stations except in Dhangadhi (Tarai). Some of the previous studies (Shrestha 2000, Shrestha et. al. 1999 and Wang et. al. 2012) suggested the relationship of summer monsoon of Nepal with southern oscillation index (SOI). Proper management of water resources and regular monitoring of potential regions at high risk of drought is essential for managing drought condition in far and mid western regions.

\section{Acknowledgements}

The author would like to thank Nepal Academy of Science and Technology (NAST) for providing opportunity to carry out this research as a Research Fellow and Prof. Dr. Farindra Prasad Neupane for his great effort in reviwing this article and his fruitful suggestions. Thanks are extended to Mr. Ishwor Khanal, Chief of Faculty of Science and Dr. Bhojraj Pant, Talent Promotion Program (PhD Unit) for providing necessary datasets needed for this study and promotion division for their untiring effort in publishing this article.

\section{References}

Agnew, C. 2000. Using the SPI to identify drought. Drought Network News 12(1): 6-12.

Baidya, S.K., M.L. Shrestha, Muhammad and Munir Sheikh. 2008. Trends in daily climatic extremes of temperature and precipitation in Nepal. Journal of Hydrology and Meteorology 5(1): 38-51.

DIHM. 2004. Climatological and surface water records from 1965 to 1973. Department of Irrigation, Hydrology and Meteorology. HMG Nepal.

Gautam, D.K. and S.K. Regmi 2014. Recent trends in the onset and withdrawal of summer monsoon over Nepal. ECOPERSIA 1(4): 353-367.

Guttman, N., J. Wallis and J. Hosking. 1992. Spatial comparability of the Palmer drought severity index. Water Resources Bulletin 28(6): 1111-1119.

Sheffield, J. and E. F. Wood. 2008. Projected changes in drought occurrence under future global warming from multi-model, multi-scenario, IPCC AR4 simulations. Clim. Dyn. 31:79-105.

Kogan, F., T. A., and W., Guo 2013. Global and regional drought dynamics in the climate warming era. Remote Sensing Letters 4(4):364-372
Kundzewicz, Z. W. 1997. Water resources for sustainable development. Hvdrol. Sci. J. 42(4): 467-480.

Kafle, H. K. and H. J. Bruins 2009. Climatic trends in Israel 1970- 2002: warmer and increasing aridity inland. Journal of Climatic Change 29: 63-77. [DOI 10.1007/ s10584-009- 9578-2].

Manandhar, S., S.V. Dietrich., R.P. Sylvain and K. Futaba. 2011. Adapting cropping systems to climate change in Nepal: a cross-regional study of farmers, perception and practices, Reg. Environ. Change 11:335-348. [DOI 10.1007/s10113-010-0137-1].

McKee, T., N. Doesken and J. Kleist. 1995. Drought monitoring with multiple time scales. In: $9^{\text {th }}$ Conference on Applied Climatology, 15-20 Jan., 1995, Dallas, USA, pp.233-236.

MOE. 2010, National adaptation programme of action to climate change. Ministry of Environment, Kathmandu, Nepal.

Palmer, W. 1965. Meteorological drought. Research paper 45, US Weather Bureau, Washington, D.C.

Practical Action Nepal Office. 2009. Temporal and spatial variability of climate change over Nepal (1976-2005). ISBN: 978-9937-8135-2-5, http://practicalaction.org/ file/region_nepal/Climate Change 1976-2005.pdf (accessed on 10/27/2014).

Rees, H. G. and D. N. Collins. 2006. Regional differences in response of flow in glacier-fed Himalayan rivers to climatic warming. Hydrological Processes 20: $2157-$ 2169.

Shakya, N. and Y. Yamaguchi 2010. Vegetation, water and thermal stress index for study of drought in Nepal and central northeastern India. International Journal of Remote Sensing 31(4): 903-912.

Sharma, C.K. 1979. Partial drought conditions in Nepal, Hydrological Sciences Bulletin des Sciences Hydrologiques. 24(3): 327-333.

Saha, K. 2010. Monsoon over Southern Asia. Tropical Circulation Systems and Monsoons. Springer, pp 89-122.

Sheffield, J. and E.F. Wood. 2008. Global trends and variability in soil moisture and drought characteristics, 1950-2000, from observation-driven simulations of the terrestrial hydrologic cycle. Journal of Climate 21:432-458.

Shrestha, A.B., C.P. Wake, P. A. Mayewski and J.E. Dibbl. 1999. Maximum temperature trends in the Himalaya and its vicinity: An analysis based on temperature records from Nepal for the period 1971-94. Journal of Climate 12:2775-2787.

Shrestha, M.L. 2000. Interannual variation of summer monsson rainfall over Nepal and its relation to Southern Oscillation Index. Journal of Meteorology and Atmospheric Physics 75(1-2):21-28.

Sigdel, M. and M. Ikeda. 2010. Spatial and temporal analysis of drought in Nepal using standardized 
Hemu Kharel Kafle/Spatial and Temporal Variation.........

precipitation index and its relationship with climate indices. Journal of Hydrology and Meteorology 7(1): 59-74.

Thronthwaite, C.W. 1931. The climates of North America: According to a new classification. Geographical Review 21(4): 633-655.

Thronthwaite, C.W. 1933. The climates of earth. Geographical Review 23: 433-440.

Thronthwaite, C.W. 1948. An approach towards a rational classification of climate. Geographical Review 38: 55-94.

Thronthwaite, C.W.1957. Instructions and tables for computing potential evapotranspiration and the water balance. Publications in Climatology X(3): 185-243.
Tsakiris, G. and H. Vangelis 2005. Establishing a drought index incorporating evapotranspiration. European Water 9/10:3-11.

Trenberth, K.E., A. Dai, S. G. vander, P. D. Jones, J. Barichivich, K.R Briffa, J. Sheffield 2014. Global warming and changes in drought. Nature Clim. Change 4(1):17-22.

UNFCO. 2013. An overview of the mid western region of Nepal. UN Field Coordination Office, Adarshanagar, Surkhet Road, P.O.Box: 88, Nepalgunj-13, Banke.

UNEP. 1992. World atlas of desertification. Edward Arnold, London.

Wilhite, D.A. 2000. Drought as natural hazards: concepts and definitions. In: Drought: a global assessment, vol.1 (Ed. D. Whilhite).Routledge Publishers, London. pp 3-18.

www.lgcdp.gov.np/home/map-center.php 
Nepal Journal of Science and Technology Vol. 15, No.2 (2014) 65-76 